\title{
Seaweed cultivation on the Southern and Southeastern Brazilian Coast
}

\author{
Franciane Pellizzari, ${ }^{, 1}$ Renata Perpetuo Reis ${ }^{2}$
}

${ }^{1}$ Universidade Estadual do Paraná, Campus Fafipar, Departamento de Ciências Biológicas, Laboratório de Ficologia e Qualidade de Água do Mar, Brazil, ${ }^{2}$ Instituto de Pesquisas Jardim Botânico do Rio de Janeiro, Brazil.

Revista Brasileira de Farmacognosia

\section{Article}

\begin{abstract}
Seaweeds are used directly as food or applied indirectly as texturing agents with gelling and thickening properties (carrageenan, agar and alginates) in many industries. They can also be used as fertilizers, animal feed, biomass for fuel, cosmetics and a source of pharmaceuticals, among other applications. The aquaculture of macroalgae is an alternative for producing raw material. Brazil has a coastline with numerous locations suitable for this endeavor. However, despite the known economical and social relevance of seaweed cultivation, Brazilians do not have tradition of using edible seaweeds. In general, the raw material for indirect use (e.g., as a texturing agent) is imported. Consequently, seaweed aquaculture is still incipient in Brazil. This contribution presents data and information about macroalgae cultivation on commercial and experimental scales performed on the Southern and Southeastern Brazilian Coastline, as well as a brief overview of research related to some species cultivated in the last decade.
\end{abstract}

Received 27 Jan 2011

Accepted 10 Feb 2011

Available online 15 Apr 2011

Keywords:

Seaweed cultivation

social-economic importance potential uses macroalgae

ISSN 0102-695X doi: $10.1590 / \mathrm{S} 0102-695 \mathrm{X} 2011005000057$

\section{Introduction}

Seaweeds are used directly as food (nori, aonori, kombu, wakame, seagrapes and others) or indirectly as a texturing agent, with gelling and thickening properties (carrageenan, agar, and alginates) in the biotechnology, pharmaceutical, cosmetic, textile and food industries. They are also applied as fertilizers (and or as a foliar spray) and soil conditioners, animal feed, and biomass for fuel (Mc Hugh, 2003). The environmental, economic and social relevance of macroalgae cultivation and their potential uses around the world are well known. In addition, seaweed aquaculture can reduce fishing pressure, mitigate eutrophication and become an alternative occupation and source of income for coastal dwellers. In Zanzibar, Africa, the rural migration was reduced and the quality of life of the farmers improved (Msuya, 2006; Pickering et al., 2007). Brazil has an extensive coastline with tropical and subtropical waters suitable for seaweed aquaculture (Oliveira, 2006). Unfortunately, Brazilians do not have a tradition of consuming edible seaweed and most of the raw material for indirect use is imported. Consequently, seaweed aquaculture is still incipient in Brazil (Oliveira, 2006; Reis et al., 2007).

A review of seaweed cultivation on commercial and experimental scales in the natural habitat and in tanks in Southern and Southeastern Brazil is presented here. In addition, we provide an overview of experimental studies performed in the last decade using commercial target species.

\section{Cultivation on the Southern Brazilian coast}

In Southern Brazil, there is no seaweed cultivation on either an artisanal or commercial scale. However, several experimental cultivations have been performed, mainly focusing on Chlorophyta and Rhodophyta. The algal biomass produced was mainly used to verify the potential for bioremediation, reducing nutrients in integrated marine/estuarine cultivations, and was used as a food supply, for carrageen extraction, and for cosmetic products.

\section{Rio Grande do Sul State}

Tormenta (2006) and Tormenta et al. (2007) studied the performance of Ulva clathrata and $U$. ramulosa, respectively, as a biofilter in an estuarine lagoon in an integrated cultivation with the shrimp Litopenaeus vannamei. Tormenta et al. (2007) studied the performance of $U$. ramulosa in a shrimp cultivation tank and observed a reduction in ammonium, nitrite and nitrate concentrations, while phosphate concentrations were reduced only during the first week. These data suggest that $U$. ramulosa was efficient mainly for the assimilation of nitrogenated compounds.

Copertino et al. (2009) studied the growth rate, biofiltration efficiency and uptake rates of Ulva 
clathrata in outdoor tanks that received waste water from a shrimp (Litopenaeus vannamei) aquaculture pond adjacent to the Patos Lagoon estuary. U. clathrata was efficient at removing the main inorganic nutrients from effluent water, stripping $70-82 \%$ of the total ammonium nitrogen and $50 \%$ of the phosphate within 15 $\mathrm{h}$. This pilot cultivation also showed that chlorophyll-a decreased in seaweed tanks, suggesting that the reduction of nitrogen compounds by $U$. clathrata can inhibit phytoplankton growth, probably by nutrient competition.

\section{Santa Catarina State}

Despite being one of the Brazilian States where aquiculture activities are well developed (mainly oyster, mussel and shrimp cultivations), no cultivations of seaweeds a large scale have been performed in Santa Catarina.

Salles et al. (2010) developed a pilot cultivation of Gracilaria domingensis (Rhodophyta) in a mussel farm located in an urbanized area of Florianopolis. Growth rates were used to evaluate the distinct methods of cultivation. The cultivation was feasible only when protected by net cages due herbivory issues and the tie-tie attachment method showed the best results. Experiments were also performed to evaluate the potential of the green seaweed Ulva lactuca as a biofilter for treatment of effluents from white shrimp (Litopenaeus vannamei) cultivation using integrated tanks. The chemical indicators used for this assessment were the concentrations of nitrogen and phosphate compounds (Alencar et al., in press).

Hayashi et al. (2010) cultivated four strains of a carrageen source species, Kappaphycus alvarezii (Rhodophyta), during one year on a floating raft near a mussel farm in Florianópolis. A positive correlation was observed between the growth rate and the water temperature, with higher growth rates $\left(5.12-4.29 \%\right.$ day $\left.^{-1}\right)$ in summer and autumn and lower growth rates $\left(0.54-0.32 \%\right.$ day $\left.^{-1}\right)$ during winter. The brown tetrasporophytic strain was excluded from the experiments due to unfeasible results. Carrageenan yields were similar between the strains analyzed and were higher in the seedlings cultivated during 42 days in the sea $(28 \%)$ and lower in the ones cultivated during 36 and 97 days $(25 \%)$, while the viscosity increased with increasing days of cultivation. Gel strength varied during the cultivation period. The environmental risk of introduction of the algae was monitored and no reproductive structures and/or recruits were observed in the field. Regarding water quality, analyses in the mussel and seaweed cultivation areas inicated a decrease in the dissolved inorganic nitrogen concentration in the seaweed cultivation area, suggesting the ability of macroalgae thalli to mitigate eutrophication.

\section{Paraná State}

Chlorophytes belonging to the Monostroma Complex are the only seaweed resource traditionally exploited in Southern Brazil, especially in Paraná state. They were harvested from natural beds (mainly in the Paranaguá Estuarine Complex) between the decades of 1970 and 1980 by local fishermen and sold dry at $c a$. US\$ $10 \mathrm{~kg}^{-1}$ dry weight (DW) to restaurants in São Paulo. However, the production was erratic, the consumption restricted and the economic impact very small. Recently, this autochthonous activity was discontinued due to several factors, including the decrease of natural stock, insufficient knowledge of species biology and the lack of technology for cultivation, unstable productivity and the absence of a well-defined market and of frond quality control.

Species of the Monostroma Complex are cultivated in China and Japan mainly for seasoning in traditional cuisine named "aonori" or "hitoegusa". The application of Monostroma by the food industry in Brazil is incipient. However, the world market for Monostroma is increasing due to a demand by the cosmetics industry, which holds several international patents. Monostroma uses in cosmetics are broad and include applications such as skin hydration or the tension and lifting effect of the aqueous mucilage extract. Chen \& Chen (2003) also reported a potential for stimulation of collagen synthesis and antioxidant and photoprotector bioactivities. Since Brazil occupies the third position worldwide in cosmetics consumption and has relevant manufacturing and production of cosmetics, this suggests a new niche that could be profitably explored, justifying Monostroma cultivation in Southern Brazil.

Pellizzari et al. (2007) studied the biological and technical aspects of cultivating Monostroma on a pilot scale at Maciel Tidal Creek (Paranaguá Bay, Paraná). The Brazilian species of Monostroma is a new taxon and it is been described based on ontogenic, molecular and chemical features. Brazil has two species of monostromatic green seaweeds: Gayralia oxysperma and Monostroma sp. However, the life cycle, ontogeny and phenological features of the genera are quite distinct, guiding cultivation endeavors. Pellizzari et al. (2008) studied these populations in Paraná and found that $G$. oxysperma is concentrated in the inner sectors of estuaries and shows low growth rates (GR). It is therefore not recommended for cultivation at this site, in spite of having been commercially used in Hawaii and France. In contrast, Monostroma sp. concentrates in the outer sector of Paraná estuaries, where higher salinities predominate and the GR is higher, being more 
suitable for cultivation.

The technique used to cultivate this seaweed consists of the use of artisanally manufactured polypropylene nets $(2.5 \mathrm{~mm}$ Ǿ; $5 \mathrm{~m}$ long x $1 \mathrm{~m}$ wide and $16 \mathrm{~cm}$ mesh) suspended by floating systems in shallow subtidal areas or set by fixed systems using bamboo poles in the intertidal zone .

The better locations for natural recruitment, starting from asexual zooids, and for frond development are the outer sectors of estuarine systems around the mangrove fringes, where mother-fronds usually grow attached to mangrove stems and roots. The species occurs year round in Paraná, showing a peak of recruitment during early spring. Plantlets of Monostroma sp. from in vitro cultures showed tolerance to a broad range of salinity and irradiance; the highest growth rate (GR) was observed at $21.5^{\circ} \mathrm{C}$ and $100 \mu \mathrm{mol}$ photon. $\mathrm{m}^{-2} \mathrm{~s}^{-1}$ and salinities between 20 and $40 \mathrm{psu}$. In the field, the highest GR occurred during periods of lower temperature $\left(20-22^{\circ} \mathrm{C}\right)$, low rainfall, and salinities between 25 and 30 psu (Pellizzari et al., 2006). Therefore, the development is mainly limited by temperature, this being the primary physical parameter guiding the selection of cultivation areas.

Mean GR range around $\pm 6 \%$ day $^{-1}$ during winter and $\pm 3 \%$ day $^{-1}$ during summer, demonstrating that the optimum growth and coverage of the culture is during the late winter and spring. Frond size during this period was $7 \pm 2 \mathrm{~cm}$ in height. Net biomass production was $458 \pm 157$ g.m $\mathrm{m}^{-2}$ wet weight (WW), and $58 \pm 21 \mathrm{~g} . \mathrm{m}^{-2}$ DW only 45 days after starting from zooid settlement. Frond humidity was around $90 \pm 3.6 \%$ (Pellizzari et al., 2007).

Although higher GR has been observed in nets in floating rafts, the fixed systems showed stable production and few disturbances due to epiphytes, fouling and/or grazing. These systems are also simpler and cheaper to implement than floating rafts, an advantage in the productive chain for aquiculture endeavors.

Preliminary biochemical analyses (Pellizzari, 2008) support the nutraceutic and cosmetic uses of Monostroma, indicating high concentrations of calcium (863.7 $\left.\pm 86 \mathrm{mg} .100 \mathrm{~g}^{-1}\right)$, iron $\left(77.7 \pm 23 \mathrm{mg} .100 \mathrm{~g}^{-1}\right)$, and ascorbic acid $\left(486.54 \pm 92 \mathrm{mg}^{1} 100 \mathrm{~g}^{-1}\right)$ on fronds collected during winter. Bioactivity such as anti-herpes simplex virus (Cassolato et al., 2008) or anti-bacterial activity, rheological studies, antioxidant activity and vitamin content have been examined to support alternative uses of this algal group by other than the food industry in order to support larger scale cultivations.

The food market for seaweeds in Southern Brazil is quite restricted. For this reason, several studies are seeking new alternative uses for seaweeds as a natural resource. Applications in cosmetics are promising due to the diversity of potential products, opening the western market. Two important European cosmetics companies are using monostromatic Chlorophyceae extracts in several product formulations, mainly for their antioxidant, photoprotective, tensioning and hydrating effects.

A higher, reliable high quality biomass production could be achieved by using the artificial seedling method, similar to that used for Porphyra (the seaweed of $s u s h i$ ). This technique consists recruitments in nets and initial plantlet development in hatcheries. The artificial recruitment starts with selected Monostroma mother plants collected in the field. After asepsis and acclimation in tanks, the fronds are induced to release reproductive cells by a temperature and/or salinity shock. Nutrient depletion also can be employed to induce zooid release, aiming at indoor net recruitment. However, as long as there is no established, fixed and safe market for this algal resource in Brazil, it is speculative and hazardous to try to invest in expensive techniques and technologies such as hatchery infrastructure. It is also currently quite risky to invest in applied but notunprecedented research in Brazil on: monostromatic green algae hybridization techniques using protoplast fusion (e.g., Hitoshi et al., 1998); development of protoplast banks as seed stock for algal mass culture, as studied in M. latissimum by Yean-Chang (1998); or temperature-resistant strain selection as recently studied by Xing-Hong et al. (2010). A successful selection of heat-resistant strains could greatly reduce the economic risks, generating an alternative production for the nor $i$ industry (and/or another commercial species) and benefitting these endeavors. However, these spectacular approaches require stimulation by a specific market, which is clearly not the case in Brazil.

The outer sector of Paranaguá and Guaratuba Bays have broad intertidal/flat areas where there are no conflicts with other activities (e.g., navigation, fishing or harbor activities). Although the potential for growth of Monostroma on the Paraná coast is quite impressive and several artisanal methods of cultivation are viable and complementary, several cultural and political issues do not provide a boost for seaweed aquiculture. Therefore, social and cultural readjustments are required to leverage this activity, mainly regarding the way fishermen think (a waiting period prior to earning income is not well accepted) the adaptation of this activity for female labor. These issues could be minimized by environmental education focused on social inclusion of specific coastal communities. Moreover, diversification of products and/or the development of alternative uses for Monostroma are prime elements in the expansion of the internal market, starting with cosmetic natural products.

The simplicity of Monostroma cultivation methods, the high growth rates and the extensive areas 
in South Brazil that are suitable for cultivation suggest that this activity may become a good alternative for income in coastal communities in the near future, in addition to expanding the Brazilian market for seaweeds.

At present, a feasibility study for introduction of Kappaphycus alvarezii is also underway at Ilha do Mel (Bernardi et al., unpublished results).

\section{Cultivation on the Southeastern Brazilian coast}

In the last decade, São Paulo and Rio de Janeiro States implemented commercial cultivation of the seaweed Kappaphycus alvarezii. This seaweed is cultivated as raw material for a small Brazilian carrageenan industry (Ondas Biomar Cultivo de Algas Marinhas Ltda.), but it is not sufficient to supply the national demand for carrageenan (Reis et al., 2007). The Brazilian annual carrageenan importation in the last decade was around nine millions American dollars (http://aliceweb.desenvolvimento.gov.br/).

The other species used as a source of carrageenan raw material is Hypnea musciformis (Wunfen in Jacqu.) J.V.Lamour. (Rhodophyta), exploited on the northeastern Brazilian coast (Reis et al., 2008). In the last decade, experimental cultivation studies have been developed (Reis et al., 2005; 2006), but until now no commercial cultivation exists.

The principal use of carrageenan is by the processed food industry as a texturing agent and stabilizer. New uses include pharmaceuticals and nutraceuticals (Pickering et al., 2007). In spite of the economic crisis, the international carrageenan demand has increased about 4\% in the last decade, In 2009, the production was 50000 metric tons with sales of 527 million American dollars. Kappaphycus alvarezii provides the brittle gel-forming kappa carrageenan that is sold as a powder. Recently, the carrageenan market increased after the US FDA allowed the use of the cheaper semi-refined carrageenan for human consumption instead of the refined extract. The European Commission and the FAO/WHO Codex Alimentarius require an indication on the ingredient labels of the kind of carrageenan that is being used (carrageenan or E-407 for refined carrageenan and PES or E-407a for a semirefined carrageenan). In the carrageenan companies, the primary product is blended for many applications to obtain the desired final product and the technical details are not divulged (Bixler \& Porse, 2011).

$K$. alvarezii from the tropical Indo-Pacific areas (Ask \& Azanza, 2002) has been introduced into tropical countries for aquaculture purposes (Pickering et al., 2007; Castelar et al., 2009a,b). In 1995, this species was experimentally introduced on the northern coast of São Paulo State (Paula et al., 1999). In 1998, commercial cultivation of $K$. alvarezii began at Ilha Grande Bay in the South of Rio de Janeiro State and, in 2003, the activity was expanded to Sepetiba Bay (Reis et al., 2007; Castelar et al., 2009a,b). At present, these bays are the main areas of Brazilian commercial K. alvarezii cultivation (Castelar et al., 2009b) cultivation has now been allowed from Sepetiba bay, Rio de Janeiro state, to Ilhabela, São Paulo state, by the IN 185/IBAMA (Brazilian Environmental Institute) and new farms are being established (Goes \& Reis, 2010).

\section{São Paulo State}

The first studies with $K$. alvarezii and $K$. strirum Schmitz were developed in São Paulo State. Several experimental cultivations studied the environmental risk and feasibility of $K$. alvarezii aquaculture (Paula et al., 1999, 2001, 2002; Paula \& Pereira, 2003; Bulboa \& Paula, 2005; Hayashi et al., 2007a,b) and $K$. striatum commercial farming (Bulboa \& Paula, 2005; Bulboa et al., 2007, 2008) at Ubatuba. K. striatum presented commercially satisfactory growth rates (4.3 to $6.4 \% \cdot$ day $\left.^{-1}\right)$, but the cultivation was stopped due to the production of viable tetraspores. In contrast, $\mathrm{K}$. alvarezii, which also has high commercial growth rates (3.8 to $10.7 \%$ day $^{-1}$ ), produced unviable tetraspores and was consequently considered to rrepresent a lower environmental risk for accidental introduction (Paula et al., 1999, 2002, Bulboa et al., 2007, 2008).

Other studies related to the improvement of $K$. alvarezii cultivation evaluated the effect of density, proof and time of cultivation on the growth and carrageenan yields. Higher productivity was obtained between 44 and 59 days, higher carrageenan yields were in seedlings cultivated during 28 days and higher molecular weight and gel strength were obtained in older tissues (Hayashi et al., 2007a). Four strains of $K$. alvarezii (brown, green and red tetrasporophytic strains, and one strain derived from tetraspores progeny, called Edison de Paula- EP) were investigated regarding growth rate, semi-refined and refined carrageenan yields, 3,6-anhydrogalactose and sulfate content and gel strength. From summer to autumn, the strains had higher growth rates, decreasing in the winter. Despite the lower growth rates of the EP strain, the semi-refined and refined carrageenan yields were higher compared with the other strains. A negative correlation was obtained between growth rate and semi-refined carrageenan yield. The brown strain had the lowest content of 3,6-anhydrogalactose, while the EP and green strains showed higher values. Sulfate content and gel strength did not present a pattern of variation or a causal relationship (Hayashi et al., 2007b).

The efficiency of this alga as a biofilter was demonstrated in experiments that used fish tank water discharged into $K$. alvarezii cultivation tanks. The 
efficiency of $K$. alvarezii in remediating euthrophication was demonstrated by removal of around $80 \%$ of the ammonium and $26 \%$ of the phosphate (Hayashi et al., 2008). This seaweed has also been cultivated with the Pacific white shrimp Litopenaeus vannamei in floating cages. The floating cage was suggested to be an alternative for cultivating the shrimp, but the growth rate of the seaweed was not adequate for commercial growth (Lombardi et al., 2006), probably due to shading.

The influence of population densities of mobile and semi-sessile phytal macrofauna on the growth of $K$. alvarezii was tested in an experimental cultivation at Ubatuba. The macrofauna varied seasonally. Amphipods dominated and the detritivorous-suspensivorous species dominated the macrofauna. Partial correlations between macrofaunal taxa and species variables and the thallus growth rate within each season showed that tubicolous amphipods were the most effective group, accounting for the differences in algal growth rate in winter (Lopes, 2007).

\section{Rio de Janeiro State}

The invasive risk of $K$. alvarezii on the Southern coast of Rio de Janeiro State was evaluated through environmental monitoring aimed at verifying the establishment of $K$. alvarezii spores and seedling lost from three commercial farms at Sepetiba and Ilha Grande Bays. After more than ten years of commercial cultivation in Rio de Janeiro State, no invasion process was observed and its invasive potential in this state was considered to be remote. However, conservation measures such as the need to establish specific environmental monitoring protocols for $K$. alvarezii cultivation and quarantine protocols for new strains were suggested (Castelar et al., 2009a,b).

The influence of biofouling on $K$. alvarezii farming production was analyzed on commercial floating rafts at the Sepetiba bay by evaluating seedling damage caused by epibionts and endobionts. The richness, diversity and total biomass varied significantly during the year studied. The biofouling biomass was not found to have a significant effect on the $K$. alvarezii daily growth rate, carrageenan yield, or gel strength and viscosity (Marroig \& Reis, 2010).

The two cultivation techniques used in Brazil (tie-tie and tubular netting techniques) were compared. The tubular net technique was considered to be more effective than the tie-tie technique since the cultivation management (time used to plant and harvest the seedlings) was faster (54\%), no seedlings were lost, material costs were lower and, in one year, a return near $20 \%$ was estimated, superior to the tie-tie technique (Goes \& Reis, 2010).
Reis et al. (2005) cultivated Gracilaria caudata J.Agardh, G. cervicornis (Turner) J. Agardh and Hypnea musciformis experimentally in Sepetiba Bay on long lines using the tie-tie technique. After 20 and 40 days of cultivation, the daily growth rates were compared. $H$. musciformis had the highest growth rates and the decrease in biomass was attributed to as increase of amphipod herbivore activity. From spring 2003 to winter 2005, Reis et al. (2006) cultivated H. musciformis at the same site using nine different techniques for seedlings on the ropes (long-lines). Positive growth rates were obtained from winter 2004 to winter 2005. The negative results were attributed to environmental factors such as rough seas and anthropogenic activities that broke the cultivation structures, the adherence of organic matter to the seedlings and herbivore pressure. The easiest and cheapest technique was the use of a clamp to fix the seedlings.

The abiotic requirements for a better $K$. alvarezii production in aquaculture are within the parameters measured on the Brazilian coastline. The temperature must be above $20{ }^{\circ} \mathrm{C}$ and the optimum temperature is between 25 and $28{ }^{\circ} \mathrm{C}$ (Doty, 1987; Ask \& Azanza 2002; Paula \& Pereira, 2003), salinity between 30 and 40 (Ask \& Azanza, 2002; Reis et al., 2010) and irradiation of 100 to $1000 \mu \mathrm{mol}$. photons. $\mathrm{m}^{2} \mathrm{~s}^{-1}$ (Granbom et al., 2001). In the Brazilian northeast, the presence of coral reefs could be an environmental risk for $K$. alvarezii aquaculture. The native macroalgae Hypnea musciformis can be an alternative species for raw material for the carrageenan market, but improvements are needed in the cultivation technology (Reis et al., 2007). Experimental cultivations of this species, using tubular nets, are successful so far and the partnership between Government, Brazil Bank and carrageenan industry (Ondas Biomar) is a promissing enterprise for improving this aquaculture in Ceará State (Góes, personal communication).

In Santa Catarina State, the feasibility of $K$. alvarezii cultivation was confirmed in spite of low temperatures, mainly at winter months. Bioremediation can be applied in this state to cultivate this seaweed, intercropped with mussels to mitigate the euthrophication and improve the economic return of both aquacultures. No environmental risk was observed in the experimental area and the Brazilian Environmental Institute (Ibama) is analyzing the request for permission to cultivate $K$. alvarezii in this area (Hayashi et al., 2010).

Since $K$. alvarezii is an exotic species, the Government document (IN 185/Ibama) that allowed the cultivation of this alga determined that the environment needs to be monitored periodically as a precaution to avoid the establishment of this exotic species in the biota. The company that cultivates this alga in Rio de Janeiro State periodically publishes environmental reports. The Government needs to create an environmental conscience. 
Macroalgae cultivation can be beneficial to the environment, providing refuge and food for other organisms (Paula \& Pereira, 1998), and can decrease euthrophication by associating with other aquacultures such as bivalves and fish (Neori et al., 2004).

The success of algal aquaculture demands partnership between academy, people involved in biomass production and Government, aiming at providing technological improvements and preventive protocols. The most important macroalgal species used in aquaculture comes from scientific research that elucidated life histories, optimization of the growth and production of the desired economic product (Santelices, 1999; Wikfors \& Ohno, 2001; Ask \& Azanza, 2002).

An example of research relevant to aquaculture comes from the detection of several environmental factors that were responsible for a huge loss in the biomass of $K$. alvarezii during farming, caused mainly by diseases such as ice ice and goose pump. The former was caused by drops on salinity and an increase in temperature and the latter (goose pump) by bacteriological infection after epiphitism by Neosiphonia apiculata (Hollenberg) Masuda et Kogame (Hurtado et al., 2008, Vairappan et al., 2008).

Regarding Brazilian seaweed aquaculture, there is an urgent need to identify suitable sites and or to establish aquaculture parks along the coastline, in addition to legal actions to leverage the cultivation of native and/or exotic species. These provisions will probably strengthen research, generating knowledge on strain selection, improvement of growth, and resistance to disease; this should result in an upgrade in the quality of products extracted from algal resources and applied for pharmacological, cosmetic, hydrocolloids and nutritional purposes. In addition, political strategies against the environmental risk of invasion, such as quarantine and specific environmental monitoring protocols, should be legalized.

\section{Acknowledgements}

This work was supported by Ondas Biomar Cultivo de Algas, Ltda., FAPERJ, CAPES and CNPq. We would like to thank Paulo Antunes Horta (UFSC) and Margareth Copertino (FURG) for kindly sending information about cultivation studies in Santa Catarina and Rio Grande do Sul, respectively. We also thank Dicla Pupo for revising the manuscript.

\section{References}

Alencar JR, Celino JJ, Hayashi L, Nunes AP, Bouzon ZL, Scherner F, Fonseca A, Pagliosa P, Horta PA (in publish). The Green Seaweed Ulva lactuca potential for the treatment of the white shrimp Litopenaeus vannamei effluents in integrated tanks cultivation. $J$
Appl Phycol (in press).

Ask EI, Azanza RV 2002. Advances in cultivation technology of commercial eucheumatoid species: a review with suggestion for future research. Aquaculture 206: 257277.

Bixler HJ, Porse H 2011. A decade of change in the seaweed hydrocolloids industry. J Appl Phycol DOI 10.1007/ s10811-010-9529-3.

Bulboa CR, Paula EJ 2005. Introduction of non-native species of Kappaphycus (Rhodophyta, Gigartinales) in subtropical waters: Comparative analysis of growth rates of Kappaphycus alvarezii and Kappaphycus striatum in vitro and in the sea in southeastern Brazil. Phycol Res 53: 183-188.

Bulboa CRB, Paula EJ, Chow F 2007. Laboratory germination and sea out-planting of tetraspore progeny from Kappaphycus striatum (Rhodophyta) in subtropical waters of Brazil. J Appl Phycol 19: 357-363.

Bulboa CRB, Paula EJ, Chow F 2008. Germination and survival of tetraspores of Kappaphycus alvarezii var. alvarezii (Solieriaceae, Rhodophyta) introduced in subtropical waters of Brazil. Phycol Res 56: 39-45.

Cassolato JEF, Noseda MD, Pujol C, Pellizzari FM, Damonte EB, Duarte MER 2008. Chemical structure and antiviral activity of the sulfated heterorhamnan isolated from the green seaweed Gayralia oxysperma. Carbohydr Res 343: 3085-3095.

Castelar B, Reis RP, Bastos M 2009a. Contribuição ao programa de monitoramento ambiental da maricultura de Kappaphycus alvarezii (Doty) Doty ex P. C. Silva (Rhodophyta-Solieriaceae) na Baía de Sepetiba, RJ, Brasil Acta Bot Brasil 23: 613-617.

Castelar B, Reis, RP, Moura A, Kirk R 2009b. Invasive potential of off the south coast of Rio de Janeiro state, Brazil: a contribution to environmentally secure cultivation in the tropics. Bot Mar 52: 283-289.

Chen RH, Chen WY 2003. Skin hydration, film formation time, and physicochemical properties of a moisture mask containing Monostroma nitidum water soluble mucilage. J Cosmetic Sci 54: 9-20.

Copertino MS, Tormena T, Seeliger U 2009. Biofiltering efficiency, uptake and assimilation rates of Ulva clathrata (Roth) J. Agardh (Clorophyceae) cultivated in shrimp aquaculture waste water. J Appl Phycol 21: 31-45.

Doty MS 1987. The production and use of Eucheuma, In Doty MS, Caddy JF, Santelices B (org.) Case Studies of Seven Commercial Seaweed Resources. Rome: FAO Fish Tech Pap 281: 123-161.

Góes HG, Reis RP 2010. An initial comparison of tubular netting versus tie-tie methods of cultivation for Kappaphycus alvarezii (Rhodophyta, Solieriaceae) on the south coast of Rio de Janeiro State, Brazil. J Appl Phycol DOI: 10.1007/s10811-010-9647-y.

Granbom M, Pedersén M, Kadel P, Luning K 2001. Circadian 
rhythm of photosynthetic oxygen evolution in Kappaphycus alvarezii (Rhodophyta): dependence on light quantity and quality. J Phycol 37: 1020-1025.

Hayashi L, Oliveira EC, Bleicher-Lhonneur G, Boulenguer P, Pereira RTL, Seckendorff R, Shimoda VT, Leflamand A, Vallée P, Critchley AT 2007a. The effects of selected cultivation conditions on the carrageenan characteristics of Kappaphycus alvarezii (Rhodophyta, Solieriaceae) in Ubatuba Bay, São Paulo, Brazil. J Appl Phycol 19: 505511.

Hayashi L, Paula EJ, Chow F 2007b. Growth rate and carrageenan analyses in four strains of Kappaphycus alvarezii (Rhodophyta, Gigartinales) farmed in the subtropical waters of São Paulo State, Brazil. J Appl Phycol 19: 393-399.

Hayashi L, Santos AA, Faria GSM, Nunes BG, Souza MS, Fonseca ALD, Barreto PLM, Oliveira EC, Bouzon ZL 2010. Kappaphycus alvarezii (Rhodophyta, Areschougiaceae) cultivated in subtropical waters in Southern Brazil. J Appl Phycol. DOI 10.1007/s10811010-9543-5.

Hayashi L, Yokoya NS, Ostini S, Pereira RTL, Braga ES, Oliveira EC 2008. Nutrients removed by Kappaphycus alvarezii (Rhodophyta, Solieriaceae) in integrated cultivation with fishes in re-circulating water. Aquaculture 277: 185-191.

Hitoshi K, Kunimoto M, Kamanishi Y, Mizukami Y 1998. Protoplast fusion between Monostroma nitidum and Porphyra yezoensis and subsequent growth of hybrid plants. J Appl Phycol 10: 15-21.

Hurtado AQ, Bleisher-Lhonneur G, Crichley AT 2008. Kappaphycus 'cottonii' farming. Philippines: Integrated Services for the Development of aquaculture and Fisheries.

Lombardi JV, Marques HLA, Pereira RTL, Barreto OJS, Paula EJ 2006. Cage polyculture of the Pacific white shrimp Litopenaeus vannamei and the Philippine seaweed Kappaphycus alvarezii. Aquaculture 258: 412-415.

Lopes ESF 2007 A macrofauna fital de Kappaphycus alvarezii (Doty) Doty ex Silva e sua influência na taxa de crescimento da alga em um cultivo em Ubatuba, SP. São Paulo, 64p. Dissertação de Mestrado, Programa de Pós-graduação em Ecologia, Universidade de São Paulo.

Marroig RG, Reis RP 2010. Does biofouling influence Kappaphycus alvarezii (Doty) Doty ex Silva farming production in Brazil? J Appl Phycol DOI 10.1007/ s10811-010-9602-y.

McHugh DJ 2003. A Guide to the Seaweed Industry. Rome. FAO Fisheries Technical Paper. Food and Agriculture Organization of the United Nations.

Msuya FE 2006. The impact of seaweed farming on the social and economic structure of seaweed farming communities in Zanzibar, Tanzania In: Critchley AT, Ohno M, Largo DB (eds). World Seaweed Resources-
An authoritative reference system. ETI BioInformatcs, Amsterdam. DVD-ROM.

Neori A, Chopin T, Troell M, Buschmann A H, Kraemer GP, Halling CPM, Yarish C 2004. Integrated aquaculture: rationale, evolution and state of the art emphasizing seaweed biofiltration in modern mariculture. Aquaculture 231: 361-391.

Oliveira EC 2006. Seaweed resources of Brazil. In Critchley AT, Ohno M, Largo DB (Eds). World Seaweed Resources-An authoritative reference system. ETI BioInformatics, Amsterdam. DVD-ROM.

Paula EJ, Pereira RTL 1998. Da "marinomia" a maricultura da alga exótica, Kappaphycus alvarezii (Doty) Doty ex. Silva (Rhodophyta), para a produção de carragenanas no Brasil. Panor Aquic 8: 10-15.

Paula EJ, Pereira RTL 2003. Factors affecting growth rates of Kappaphycus alvarezii (Doty) Doty ex. P. Silva (Rhodophyta, Solieriaceae) in subtropical waters of São Paulo State, Brazil. In: Chapman ARO, Anderson RJ, Vreedland VJ, Davison IR (org) Proceedings of the $17^{\text {th }}$ International Seaweed Symposium, Cape Town: Oxford University Press, p 381-388.

Paula EJ, Erbert C, Pereira RTL 2001. Growth rate of the carragenophyte Kappaphycus alvarezii (Rhodophyta, Gigartinales) in vitro. Phycol Res 49: 155-161.

Paula EJ, Pereira RTL, Ohno M 1999. Strain selection in Kappaphycus alvarezii var. alvarezii (Doty) Doty ex P. Silva (Rhodophyta, Solieriaceae) using tetraspore progeny. J Appl Phycol 119: 111-121.

Paula EJ, Pereira RTL, Ohno M 2002. Growth rate of the carrageenophyte Kappaphycus alvarezii (Rhodophyta, Gigartinales) introduced in subtropical waters of São Paulo State, Brazil. Phycol Res 50: 1-9.

Pellizzari FM 2008. Cultivo de clorofíceas monostromáticas comestíveis no Sul do Brasil: descrição e biologia molecular da(s) espécie(s), recrutamento e crescimento em diferentes sistemas. Relatório técnico de Pós-Doutorado apresentado ao Conselho Nacional de Desenvolvimento Científico e Tecnológico, Brasil. $70 \mathrm{p}$.

Pellizzari FM, Oliveira EC, Yokoya NS 2006. Coverage and recruitment of the edible green macroalga Monostroma sp. (Monostromataceae) in Paranaguá Bay, Southern Brazil. J Coastal Res 39: 157-159.

Pellizzari FM, Yokoya NS, Oliveira EC 2007. Cultivation of the edible green seaweed Gayralia (Chlorophyta) in Southern Brazil. J Appl Plycol 19: 63-69.

Pellizzari FM, Oliveira EC, Yokoya NS 2008. Life-history, thallus ontogeny, and the effects of temperature, irradiance and salinity on growth of the edible green seaweed Gayralia spp. (Chlorophyta) from Southern Brazil. J Appl Plycol 20: 75-82.

Pickering TD, Skelton P, Sulu JR 2007. Intentional introductions of commercially harvested alien seaweeds. Bot Mar 50: 338-350. 
Reis RP, Barros-Barreto MB, Caldeira AQ Miranda APS 2005. Cultivo de algas vermelha de interesse comercial na Ilha da Marambaia, Rio de Janeiro, Brasil. Mus Nac Ser Livr 10: 287-300

Reis RP, Bastos M, Góes HG 2007. Cultivo de Kappaphycus alvarezii no litoral do Rio de Janeiro. Panor Aqüic 17: 42-47.

Reis RP, Caldeira AQ, Miranda APSM, Barros-Barreto MB 2006. Potencial para maricultura da carragenófita Hypnea musciformis (Wulfen) J. V. Lamour. (Gigartinales-Rhodophyta) na Ilha da Marambaia, Rio de Janeiro, Brasil. Acta Bot Brasil 20: 763-769.

Reis RP, Loureiro RR, Mesquita FS 2010. Does salinity affect growth and carrageenan yield of Kappaphycus alvarezii (Gigartinales/Rhodophyta)? Aquac Res Doi 10.1111/j.1365-2109.2010.02699.x

Reis RP, Yoneshigue-Valentin Y, Santos CP 2008. Spatial and temporal variation of Hypnea musciformis carrageenan (Rhodophyta-Gigartinales) from natural beds in Rio de Janeiro State, Brazil. J Appl Phycol 20: 1-8.

Salles JP, Scherner F, Fanganiello M, Bouzon ZL, Horta PA 2010. Cultivation of native seaweed Gracilaria domingensis (Rhodophyta) in Southern Brazil. Braz Arc Biol Technol 53: 633-640.

Santelices B. 1999. A conceptual framework for marine agronomy. Hydrobiol 398/399: 15-23.

Tormena T 2006. Desempenho da macroalga Ulva clathrata (Roth) J. Agardh no tratamento de efluentes de cultivo semi-intensivo do camarão Litopenaeus vannamei (Boone). Monografia de graduação, Fundação Universidade Federal do Rio Grande, Curso de
Oceanologia. Brasil.

Tormena T, Copertino MS, Lanari MO 2007. Desempenho da macroalga Ulva ramulosa no cultivo integrado ao camarão marinho Litopenaeus vannamei. XII Congresso Latino-Americano de Ciências do MarXII Colacmar Aoceano - Associação Brasileira de Oceanografia. Florianópolis, Brasil.

Vairappan CS, Chung CS, Hurtado AQ, Soya FE, Lhonneur GB, Critchley A 2008. Distribution and symptoms of epiphyte infection in major carrageenophyteproducing farms. J Appl Phycol 20: 477-483

Wikfors GH, Ohno, M 2001. Impact of algal research in aquaculture. J Phycol 37: 968-974.

Xing-Hong Y, Feng L, Chang-Jun L, Zheng Y 2010. Selection and characterization of a high-temperature tolerant strain of Porphyra haitanensis Chang et Zheng (Bangiales, Rhodophyta). J Appl Phycol 22: 511-516.

Yean-Chang C 1998. Development of protoplasts from holdfasts and vegetative thalli of Monostroma latissimum (Chlorophyta) for algal seed stock. $J$ Phycol 34: 1075-1081.

\section{*Correspondence}

Franciane Pellizzari

Universidade Estadual do Paraná, Campus Fafipar, Departamento de Ciências Biológicas, Laboratório de Ficologia e Qualidade de Água do Mar, Rua Comendador Correa Júnior, 117, 83203-280 Paranaguá-PR, Brazil

franciane.pellizzari@fafifipar.br

Tel. +55413423 3644 